\title{
УДК 338.486
}

\section{Чиняк В. В.}

vitalia.chyniak@uzhnu.edu.ua,ORCID ID: 0000-0002-3471-5632

ResearcherID: G-5409-2019

аспірант кафедри економіки і підприємництва,

старший лаборант кафедри фрізичної географії

та рачіонального природокористування,

Ужггородський національний університет, м. Ужсгород

\section{ОГЛЯД ВПЛИВУ ДИНАМІКИ ТУРИСТИЧНИХ ПОТОКІВ НА НАПОВНЕНІСТЬ ГОТЕЛЬНИХ ПІДПРИЕМСТВ ЗАКАРПАТСЬКОЇ ОБЛАСТІ В ПЕРІОД 2018-2020 РР.}

\begin{abstract}
Анотація. У статті досліджено та надано огляд впливу постійної динамічності туристичних потоків на стан наповненості малих та середніх готельних підприємств Закарпатської області в допандемічний період (2018-2019 рр.) та в період кризи (2020р.). Окреслено проблематику даного дослідження, яка полягає у характеристиці стану сектору туризму та індустрї гостинності на локальному рівні для формування подальших управлінських рішень та розроблення необхідних заходів реагування на кризові явища. На тлі подальшого поширення пандемії коронавірусної інфекції SARS-CoV-2 як на території України загалом, так і в Закарпатській області зокрема релевантність даних матеріалів лише зростає. Здійснено літературний огляд праць вітчизняних та іноземних науковців, тематика яких стосується різноманітних впливів COVID-19 на людину та суспільство (економіку України та світу, трансформації соиіальних ризиків, формування місцевих бюджетів, функціонування різних форм бізнесу, зокрема ресторанного, $i$, врешті, роль пандемії як каталізатора інноваційного розвитку високих технологій). Виокремлено низку факторів-індикаторів, які стали основними причинами ускладнень роботи підприємств, та узагальнено тенденції, які проявлялися в туристичних потоках у Закарпатській області впродовж 2000-2019 рр. (у докоронавірусний період). Динаміка 2020-2021 рр. різко контрастує з попереднім етапом, ие яскраво проілюстровано показником, який виражається відношенням загальної кількості туристів/гостей/відвідувачів готельного підприємства до його загальної кількості місиь проживання. Розроблено графіки, які демонструють різке скорочення даного показника у 2020 р. порівняно з 2018 та 2019 рр., ие явище повністю корелюється із запровадженням карантинних обмежень, метою яких було обмеження розповсюдження коронавірусної інфекиії. На базі опитування, розробленого і проведеного авторами, сформовано та охарактеризовано часткові результати окремих аспектів наукового дослідження: розглянуто напрями зовнішнього (іноземного) туристичного потоку, проведено групування держав, із яких на територію Закарпатської області прибуває найбільша кількість гостей. Надано проміжні рекомендації, які дали б змогу поступово нарощувати конкурентоспроможність туристичного сектору регіону на міжнародній арені навіть за умов глобальної пандемї.
\end{abstract}

Ключові слова: туристичний потік, індустрія гостинності, готельні підприємства, пандемія, динаміка, Закарпатська область.

\section{Chyniak Vitaliia}

vitalia.chyniak@uzhnu.edu.ua,ORCID ID:0000-0002-3471-5632

ResearcherID: G-5409-2019

Postgraduate student of the Department of Economics and Entrepreneurship, Senior Laboratory Assistant of the Department of Physical Geography

and Environmental Management,

Uzhhorod National University, Uzhhorod

\section{OVERVIEW OF THE INFLUENCE OF DYNAMICS OF TOURIST FLOWS ON THE FULLNESS OF HOTEL ENTERPRISES OF THE TRANSCARPATHIAN REGION IN THE PERIOD 2018-2020}

\footnotetext{
Abstract. The article examines and reviews the impact of constant dynamics of tourist flows on the state of occupancy of small and medium-sized hotel enterprises in the Transcarpathian region in the pre-pandemic period (2018-2019) and during the crisis (2020). The problems of this study are outlined, which is to char-
} 
acterize the state of the tourism sector and the hospitality industry at the local level for the formation of further management decisions and the development of necessary measures to respond to crises. Against the background of further spread of the SARS-CoV-2 coronavirus infection pandemic both in Ukraine in general and in the Transcarpathian region in particular, the relevance of these materials is only increasing. A literary review of the works of domestic and foreign scientists on the various impacts of COVID-19 on man and society (the economy of Ukraine and the world, the transformation of social risks, local budgets, the functioning of various forms of business, including restaurants, and finally the role of the pandemic as catalyst for innovative development of high technologies). A number of indicator factors have been identified, which have become the main causes of complications of enterprises and generalized trends that manifested themselves in tourist flows in the Transcarpathian region during 2000-2019 (in the precoronavirus period). The dynamics of 2020-2021 contrasts sharply with the previous stage, this is clearly illustrated by the indicator, which is expressed by the ratio of the total number of tourists / guests / visitors of the hotel to its total number of accommodation. The developed graphs, which show a sharp reduction of this indicator in 2020 compared to 2018 and 2019, this phenomenon is fully correlated with the introduction of quarantine restrictions, the purpose of which was to curb the spread of coronavirus infection. On the basis of the survey developed and conducted by the authors, partial results of some aspects of scientific research are also formed and characterized: directions of external (foreign) tourist flow are considered, grouping of countries from which the largest number of guests comes to Transcarpathian region. Interim recommendations have been provided that would gradually increase the competitiveness of the region's tourism sector in the international arena, even in the context of a global pandemic.

Key words: tourist flow, hospitality industry, hotel enterprises, pandemic, dynamics, Transcarpathian region.

JEL Classification: M10, O16

DOI: https://doi.org/10.36477/tourismhospcee-3-9

Постановка проблеми. До 2019 р. сектор туризму вважався однією із найбільших і найприбутковіших галузей світового господарства. Міжнародний туризм та налагоджені туристичні потоки мають великий вплив на такі ключові сектори економіки, як транспорт і зв'язок, торгівля, сільське господарство, виробництво товарів народного споживання, будівництво [1].

Проте розповсюдження коронавірусної хвороби SARS-CoV-2 у 2019-2021 рр. стало одним iз найголовніших чинників впливу як на суспільство, так і на економіку на абсолютно всіх рівнях - від глобального до місцевого (локального). Інфекція з'явилася в Азії наприкінці 2019 р., і вірус поширився на кожен континент, включаючи Антарктиду [2], а станом на 10 листопада 2021 р. в усьому світі підтверджено вже 251 млн випадків захворювання на коронавірус і 5,06 млн смертей [3].

Відчутний спад діяльності туристичної галузі був прогнозований, особливо це проявилося у регіонах, де туризм є одним 3 основних пріоритетних напрямів діяльності, наприклад у Закарпатській області [4]. Саме тому аналіз поводження та тенденцій динаміки зовнішніх туристичних потоків, а також завантаженості номерного фонду малих готельних підприємств Закарпатської області у період пандемії є важливим чинником формування подальшої стратегії функціонування як окремих елементів індустрії гостинності, так і туристичного бізнесу в цілому.

Аналіз останніх досліджень і публікацій. Дослідження, які стосуються впливу пандемії на функціонування економіки та суспільства, представлені в низці праць вітчизняних та іноземних авторів. Зокрема, розглядаються тенденції впливу COVID-19 на економіку України та світу $[5 ; 6]$; вплив пандемії на трансформацію соціального ризику [7], а також на економічні аспекти (формування місцевих бюджетів) [8] тощо.

Іноземні автори яскраво висвітлюють проблематику функціонування ресторанного бізнесу [9]; також розглядаються пандемія та постпандемічні чинники як каталізатори інноваційного розвитку технологій [10].

Постановка завдання. Мета статті полягає у висвітленні та аналізі туристичних потоків Закарпатської області в допандемічний та пандемічний періоди, диференціації країн, із яких ці потоки формуються; розгляді особливостей наповненості готельних підприємств регіону в 2018-2020 pр.

Виклад основного матеріалу дослідження. Не оминули ускладнення й Україну, де сектор туризму, навіть за умов функціонування у контексті сталого розвитку, виявився економічно найуразливішим і непристосованим до реалій пандемії.

Кожен із цих чинників значно погіршував стан окремих компонентів сектору гостинності: зв'язку та комунікацій, міжнародного сполучення, функціонування готельно-ресторанних підприємств тощо.

Загалом в Україні тенденції туристичних потоків співпадають із тенденціями у Закарпатській області, а саме спостерігається абсолютне переважання внутрішніх потоків туристів (рис. 2.) [2; 4]. Проте Закарпатська область - це регіон України, у 
якому не тільки туризм є одним з основних пріоритетних напрямів діяльності [4], регіон, який безпосередньо межує 3 чотирма європейськими державами (Польщею, Словаччиною, Угорщиною, Румунією) [2].

Проаналізувавши діаграму, можна зробити висновок, що з 2000 р. найнесприятливішою була ситуація саме із зовнішнім (іноземним) туристичним потоком, і до 2019 р. стан його так і не покращився, а навпаки, iз 2010 р. спостерігався ще більший спад числа гостей/відвідувачів/туристів з інших країн.

Що стосується 2020-2021 pр., то тут слід брати до уваги всі вищезгадані негативні чинники, які мали місце у зв'язку з пандемією COVID-19. Проте навіть у ці кризові роки зовнішній туристичний потік у Закарпатську область не припинив своє існування.

Основні країни, 3 яких прибували відвідувачі в Закарпатську область, представлені діаграмою (рис. 3). Найбільше гостей, звичайно, припадає на сусідні країни Східної та Центральної Європи (Угорщина, Словаччина та Польща становлять понад 50\% загального іноземного туристичного потоку).

Звичайно, це пов'язано з географічними особливостями, подібними архітектурними стилями міст тощо. Проте Закарпаття також багате на унікальні природні умови та пам'ятки, які є цікавими для іноземних відвідувачів. Необхідно взяти до уваги й наявність таких явищ, як діловий та стоматологічний туризм, які також роблять значний внесок у зовнішній туристичний потік, що надходить в область.

Середнє значення показника належить таким державам, як Румунія, Німеччина, Індія. Якщо

\section{Найзначніші бізнесові ускладнення}

Відміна транспортних сполучень

Скорочення кількості клієнтів

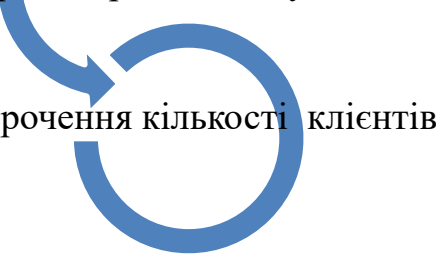

Закриття кордонів

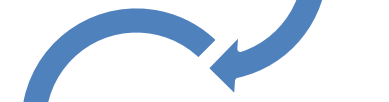

Рис. 1. Основні причини спаду діяльності підприсмств [4]

наявність стабільних туристичних зв'язків 3 європейськими країнами (рис. 4) можна пояснити територіальною близькістю, незначними культурними та менталітетними відмінностями, зручністю перетину кордону та гнучкістю візових режимів, то південноазіатський напрям сформувався на основі освітнього туризму: починаючи 32014 р. велика кількість студентів із країн Африки та Азії переїхала в Закарпатську область із метою отримання освіти 3 тимчасово окупованих територій Донецької та Луганської областей.

Найменша кількість відвідувачів спостерігається $з$ таких держав, як Молдова, Чехія, Нідерланди, Данія, Білорусь, Росія тощо. Це пояснюється особливостями соціально-політичних відносин між країнами, а також, звичайно, нововведеними обмеженнями, які стримали і без того незначний потік туристів.

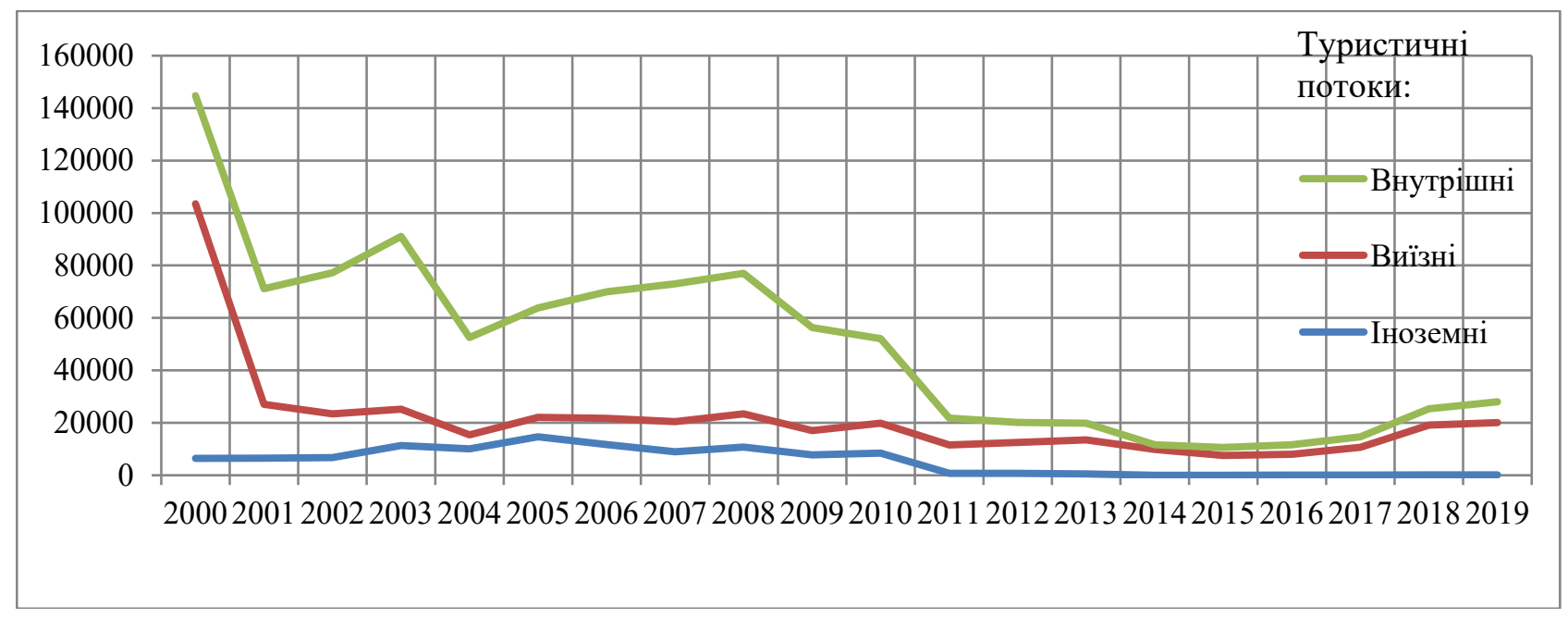

Рис. 2. Динаміка туристичних потоків у Закарпатській обл., 2000-2019 pp.

Джерело: розроблено автором на основі [11] 


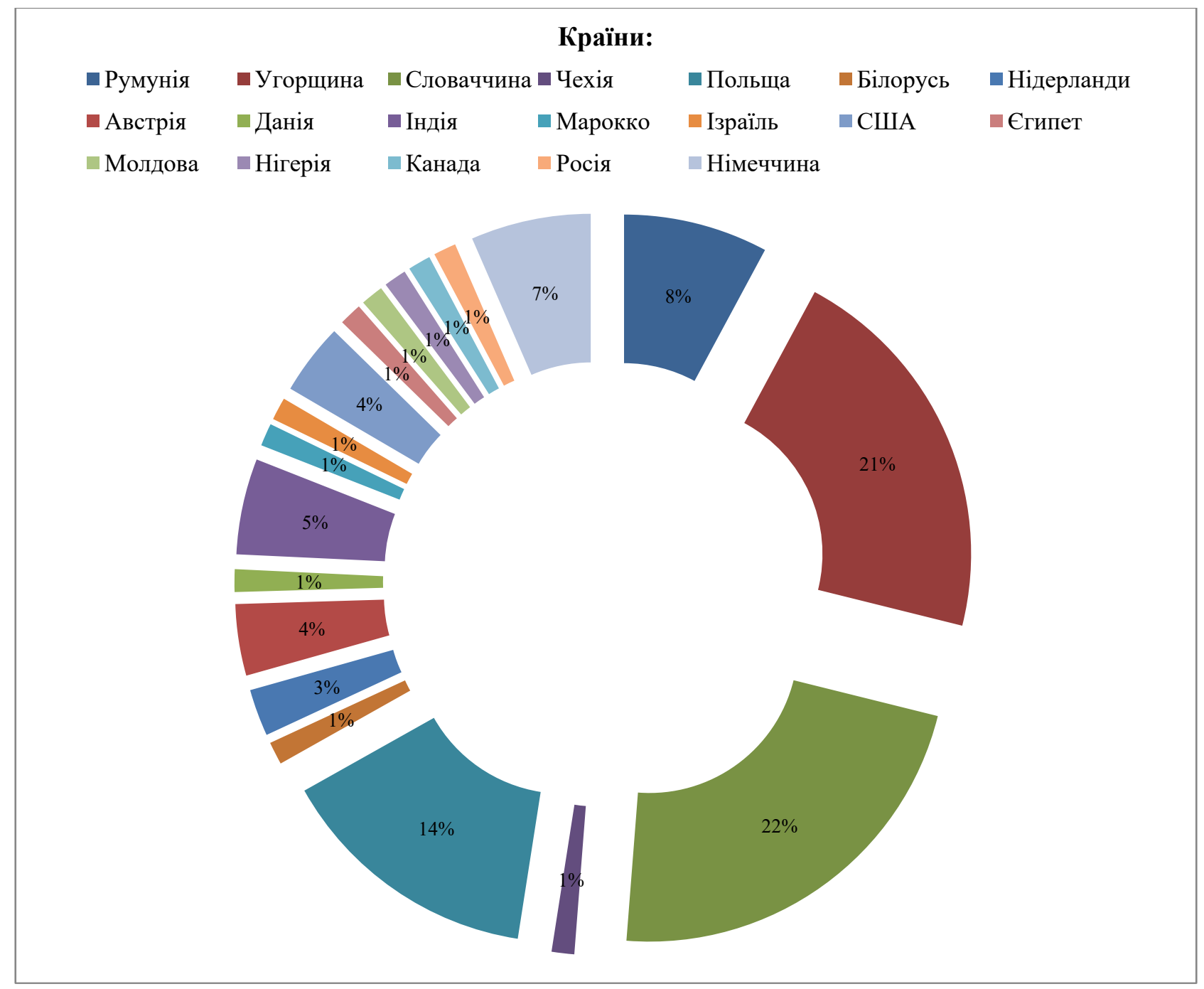

Рис. 3. Співвідношення розподілу гостей із туристичних потоків іноземних країн у Закарпатській області

Джерело: розроблено автором на основі [12]

Аналізуючи показники кількості клієнтів окремих готельних підприємств у 2018-2019 рр. (рис. 5), чітко прослідковуються такі тенденції:

- у 2018 р. середня кількість гостей, яка припадала на одне готельне місце, становила 26,02 особи/ліжко-місце;

- у 2019 р. цей показник становив 22,9 особи/ ліжко-місце, лише близько 30\% підприємств відзначали збільшення кількості гостей у 2019 р.;

- загалом у цей докризовий період середне значення показника відношення кількості клієнтів до загальної кількості місць готелю в Закарпатській області досягало 24,58 особи/ліжко-місце.

Від початку пандемії (із кінця 2019 р. - впродовж 2020 р.) значення цього показника значно зменшилося (у 2020 р. - 8,52 особи/ліжко-місце), оскільки скоротився обсяг туристичних потоків, як внутрішніх, так і зовнішніх. На рис. 6 представлено кореляцію середнього значення показника у 2018-2019 рр. для кожної компанії окремо з аналогічним показником у 2020 р.: спад $\epsilon$ абсолютно очевидним, і його причини були вищезгадані.

Висновки і перспективи подальших досліджень у даному напрямі. Розглядаючи часткові результати дослідження, можна припустити, що зовнішній (іноземний) туристичний потік - один iз найуразливіших аспектів сектору туризму не лише Закарпатської області, а й України у цілому. Доцільно було б розвивати індустрію гостинності саме в напрямі наближення конкурентоздатності до країн-сусідів: Польщі, Словаччини, Угорщини. Такі заходи, як поліпшення транспортної інфраструктури, підвищення компетентності кадрового складу, створення безпечного середовища для подорожей та позитивного іміджу галузі, допомогли б пом'якшити як наслідки пандемії, так i підвищити привабливість дестинацій Закарпаття серед іноземців. Своєю чергою, збільшення кількості відвідувачів призведе до росту надходжень 


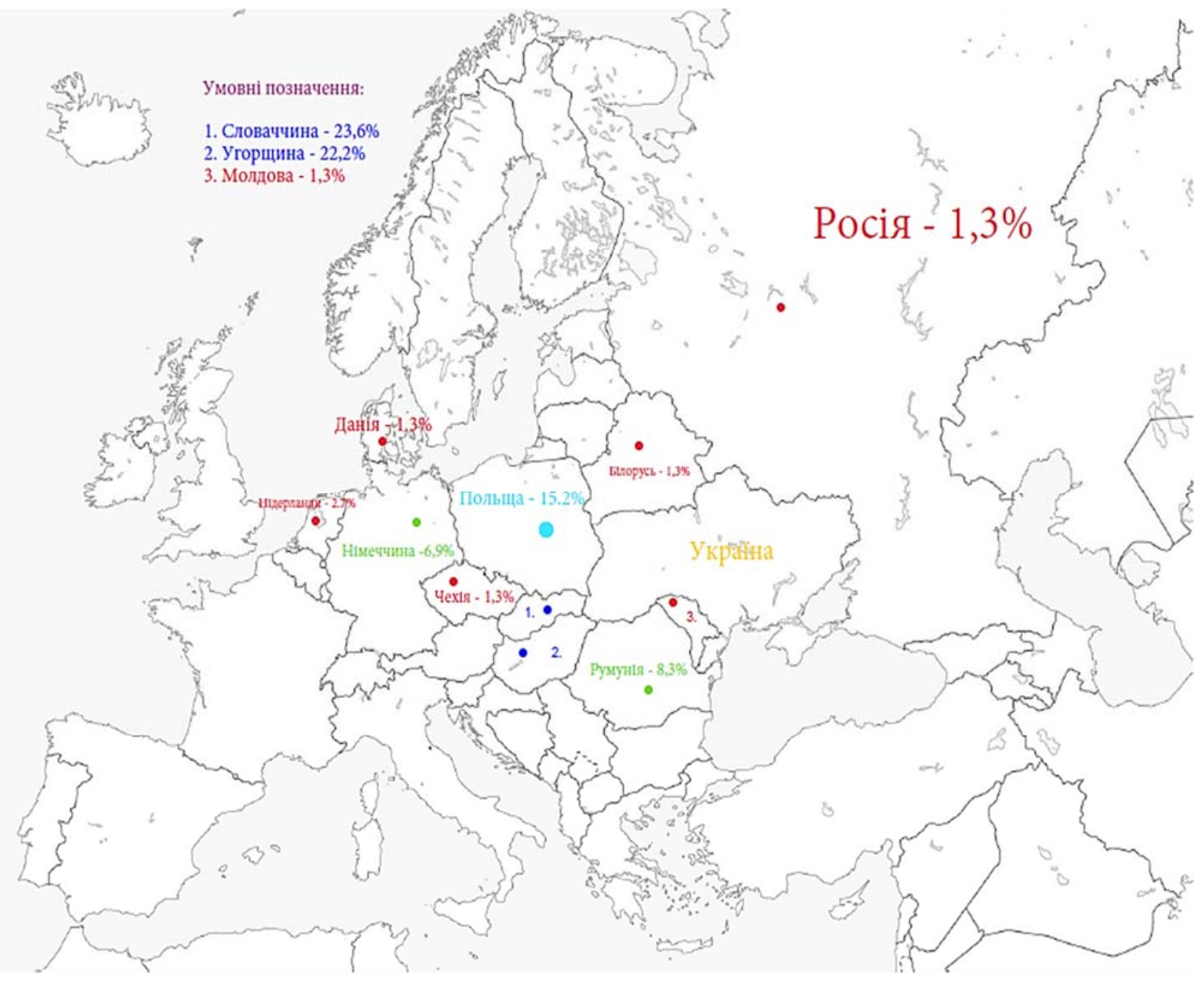

Рис. 4. Картосхема наявності туристичних потоків із країн Європи Джерело: розроблено автором на основі [12]

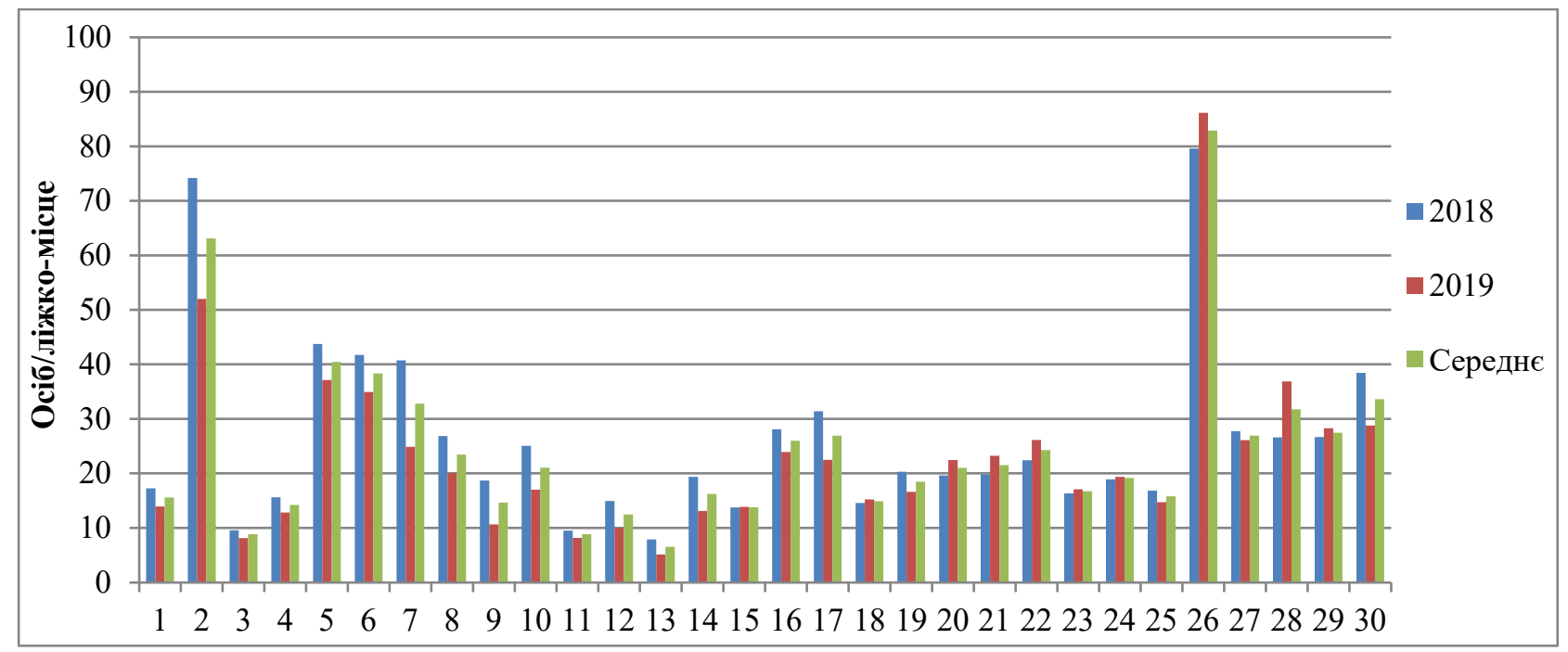

Рис. 5. Загальна кількість гостей, які припадали на одне готельне місце в 2018-2019 рр., та їх середнс значення 


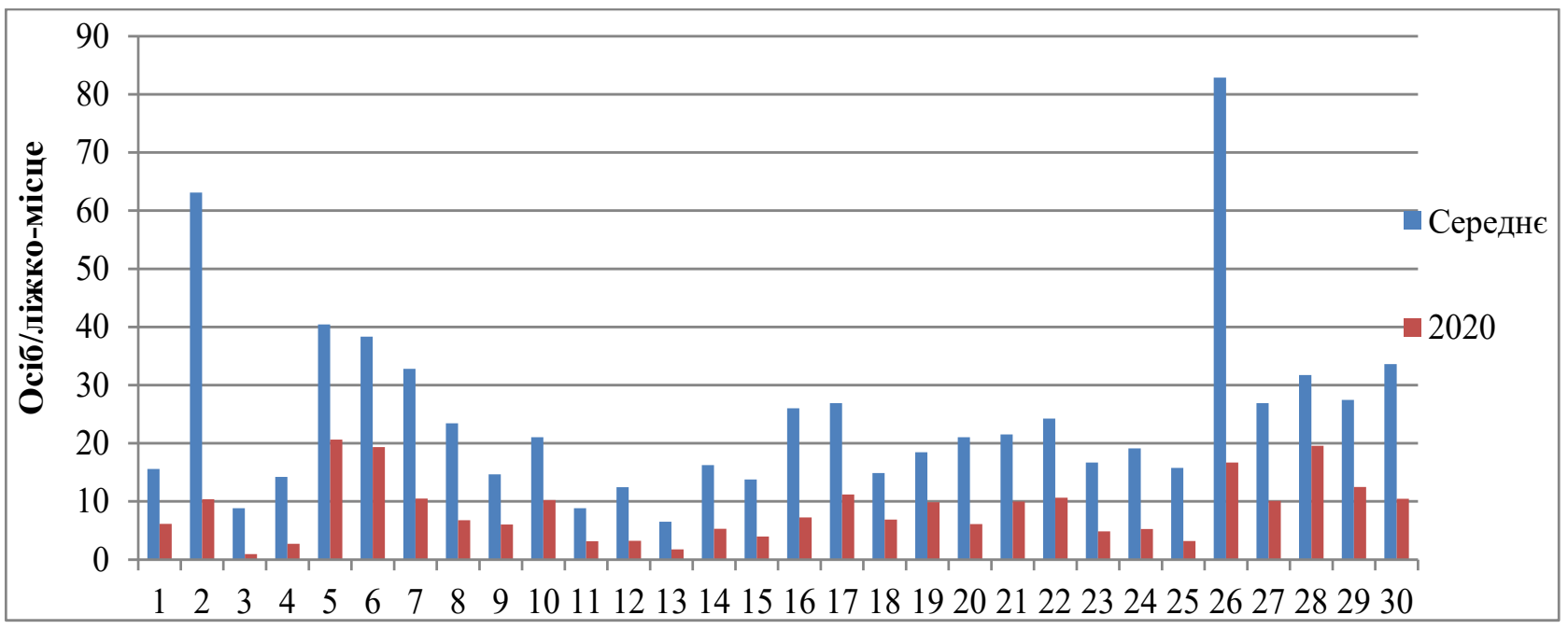

Рис. 6. Загальна кількість гостей готелів, які припадали на одне ліжко/місце у 2020 р., порівняно із середнім значенням за період 2018-2019 рр.

Джерело: розроблено автором на основі [12]

до бюджету області, що позитивно впливатиме на економічний стан держави.

У майбутніх дослідженнях варто більш детально розглянути та описати наслідки коронавірусної інфекції та іiі вплив на функціонування підприємств сфери гостинності як в Україні у цілому, так і на регіональному рівні зокрема.

\section{ЛІТЕРАТУРА}

1. Офіційний сайт Всесвітньої туристичної організації. URL: http://www.unwto.org. Назва 3 титул. екрана.

2. Слава С. С., Чиняк В. В. Аналіз динаміки туристичних потоків Закарпатської області в докризовий період. Економічний розвиток держави, регіонів $і$ підприємств: проблеми та перспективи : матеріали IV Міжнародної науковопрактичної Інтернет-конференції молодих учених, 28-29 квітня 2021 р. Львів : Львівська політехніка, 2021. C. 155-156. URL: http://http://science.inem.lviv. ua/wpcontent/uploads/2017/01/CONF_NTSA_2021pdf вільний. Заголовок з екрана.

3. Коронавірусна інфекція (COVID-19). Статистика. URL: https:/www.google.com/search?q=\%D0\% BA $\%$ D0 $\%$ BE $\%$ D $1 \% 80 \%$ D0 $\%$ BE $\%$ D $0 \%$ BD $\%$ D $0 \%$ B 0\%D0\%B2\%D1\%96\%D1\%80\%D1\%83\%D1\%81+\% D1\%81\%D1\%82\%D0\%B0\%D1\%82\%D0\%B8\%D1\% $81 \% \mathrm{D} 1 \% 82 \% \mathrm{D} 0 \% \mathrm{~B} 8 \% \mathrm{D} 0 \% \mathrm{BA} \% \mathrm{D} 0 \% \mathrm{~B} 0+\% \mathrm{D} 1 \% 8$ $1 \% \mathrm{D} 0 \% \mathrm{~B} 2 \% \mathrm{D} 1 \% 96 \% \mathrm{D} 1 \% 82 \&$ oq $=0 \mathrm{D} 0 \% \mathrm{BA} \% \mathrm{D} 0 \%$ BE $\%$ D $1 \% 80 \% \mathrm{D} 0 \% \mathrm{BE} \% \mathrm{D} 0 \% \mathrm{BD} \% \mathrm{D} 0 \% \mathrm{~B} 0 \% \mathrm{D} 0 \% \mathrm{~B} 2$ $\% \mathrm{D} 1 \% 96 \% \mathrm{D} 1 \% 80 \% \mathrm{D} 1 \% 83 \% \mathrm{D} 1 \% 81+\% \mathrm{D} 1 \% 81 \% \mathrm{D} 1$ $\% 82 \% \mathrm{D} 0 \% \mathrm{~B} 0 \% \mathrm{D} 1 \% 82 \% \mathrm{D} 0 \% \mathrm{~B} 8 \& \mathrm{aqs}=$ chrome. $1.0 \mathrm{i} 1$ 31i433j012j69i57j016.5286j1j15\&sourceid=chrome\&ie $=\mathrm{UTF}-8$.

4. Слава С. С., Чиняк В. В. Функціонування готельних підприємств Закарпатської області в умовах пандемії. Науковий вісник Одеського національного університету. Серія «Економіка». 2021.
T. 26. Вип. 2(87). С. 46-53. DOI: https://doi.org/ 10.32782/2304-0920/2-87-7.

5. Долбнєва Д. В. Вплив COVID-19 на економіку країн світу. Проблемы экономики. 2020. №. 1(43). C. 20-26. DOI: https://doi.org/10.32983/ 2222-0712-2020-1-20-26.

6. Грицюк Н. О., Сак Т. В. Вплив пандемії COVID-19 на світову економіку. Економічний проcmip. 2021. № 165. C. 33-38. DOI: https://doi.org/ 10.32782/2224-6282/165-6.

7. Білик О. І. Вплив пандемії на трансформацію соціального ризику. Право та державне управління. 2020. № 3. C. 162-167. DOI: https://doi.org/10.32840/ pdu.2020.3.24.

8. Фугело П., Савіцька С. Вплив пандемії COVID-19 на наповнення місцевих бюджетів. Економічний дискурс. 2020. Вип. 2. С. 86-94. DOI: https://doi.org/10.36742/2410-0919-2020-2-9.

9. Madeira A., Palrão T., Mendes A.S. The Impact of Pandemic Crisison the Restaurant Business. Sustainability. 2021. № 13(1). P. 40. URL: https://doi.org/ $10.3390 /$ su 13010040 .

10. Terziev, Venelinand Klimuk, Vladimir, Impactof Pandemicand Post-Pandemic FactorsonInnovativeDevelopmentofIndustry (December 01, 2020). 19th RSEP InternationalEconomics, Finance\&BusinessConference-Virtual/Online, 1-2 December 2020, Anglo-American University, Prague, Czechia. URL: https://ssrn.com/abstract=3743458.

11. Головне управління статистики в Закарпатській області. URL: http://www.uz.ukrstat.gov.ua.

12. Зведені результати анкетування ефективності факторів пристосування підприємств до функціонування в умовах пандемії. Внутрішній документ. Ужгород : УжНУ, 2021.

\section{REFERENCES}

1. Oficzijnij sajt Vsesvitnoyi turistichnoyi organizacziyi [Official site of World Tourism Organization] Retrieved April 20, 2020 from: http://www.unwto.org. 
2. Slava, S. S. and Chyniak, V. V. (2021), Analiz dynamiky turystychnykh potokiv Zakarpatskoi oblasti $\mathrm{v}$ dokryzovyi period [Analysis of the dynamics of tourist flows in the Transcarpathian region in the precrisis period]. Paper presented at The IV International Scientific and Practical Internet Conference of Young Scientists «Economic development of the state, regions and enterprises: problems and prospects», Lviv, Ukraine. Retrieved November 10, 2021 from http://http://science.inem.lviv.ua/wpcontent/uploads/ 2017/01/CONF NTSA 2021pdf. (in Ukrainian)

3. Koronavirusna infektsiia (COVID-19). Statystyka [Coronavirus infection (COVID-19). Statistics]. Retrieved November 10, 2021 from https://www.google.com/search?q=\%D0\%BA\%D0\%B E\%D1\%80\%D0\%BE\%D0\%BD\%D0\%B0\%D0\%B2\% D0\%B8\%D1\%80\%D1\%83\%D1\%81+\%D1\%81\%D1\% $82 \% \mathrm{D} 0 \% \mathrm{~B} 0 \% \mathrm{D} 1 \% 82 \% \mathrm{D} 0 \% \mathrm{~B} 8 \% \mathrm{D} 1 \% 81 \% \mathrm{D} 1 \% 82 \%$ D0\%B8\%D0\%BA\%D0\%B0+\%D0\%BC\%D0\%B8\%D $1 \% 80$ \& oq $=\% \mathrm{D} 0 \% \mathrm{BA} \% \mathrm{D} 0 \% \mathrm{BE} \% \mathrm{D} 1 \% 80 \% \mathrm{D} 0 \% \mathrm{BE} \&$ aqs $=$ chrome.2.69i57j0i131i433i457i512j69i5912j69i611 $2 \mathrm{j} 69 \mathrm{i} 65 \mathrm{j} 69 \mathrm{i} 61.6164 \mathrm{j} 0 \mathrm{j} 7$ \& sourceid $=$ chrome $\& \mathrm{ie}=\mathrm{UTF}-8$. (in Ukrainian)

4. Slava, S. S. and Chyniak, V. V. (2021), Funktsionuvannia hotelnykh pidpryiemstv Zakarpatskoi oblasti $\mathrm{v}$ umovakh pandemii [Operation of hotel enterprises in the Transcarpathian region in a pandemic]. Helvetyka [Helvetica], 2 (87), 46-53. [in Ukrainian]. DOI: https://doi.org/10.32782/2304-0920/2-87-7.

5. Dolbnieva, D. V. (2020), Vplyv COVID-19 na ekonomiku krain svitu [The impact of COVID-19 on the economies of the world]. Problemy ekonomiky [Problems of the economy], 1 (43), 20-26. Retrieved August 28, 2021, from https://www.problecon.com/article/?yea $\mathrm{r}=2020 \&$ abstract $=2020 \_1$ 0_20_26\&lang=ru [in Russian]. DOI: https://doi.org/10.32983/2222-0712-2020-120-26.

6. Hrytsiuk, N. O. and Sak, T. V. (2021), Vplyv pandemii COVID-19 na svitovu ekonomiku [The impact of the COVID-19 pandemic on the world economy]. Ekonomichnyi prostir [Economic space], 165, 33-38. Retrieved November 5, 2021, from http://prostir.pdaba.dp.ua/index.php/journal/article/ view/780.DOI:https://doi.org/10.32782/2224-6282/165-6.

7. Bilyk, O. I. (2020), Vplyv pandemii na transformatsiiu sotsialnoho ryzyku [The impact of the pandemic on the transformation of social risk]. Pravo ta derzhavne upravlinnia [Law and public administration], 3, 162-167. Retrieved November 5, 2021, from http://pdu-journal.kpu.zp.ua/archive/3_2020/26.pdf. DOI: https://doi.org/10.32840/pdu.2020.3. 24 .

8. Fuhelo Pavlina, Savitska Svitlana (2020), Vplyv pandemii covid-19 na napovnennia mistsevykh biudzhetiv [The impact of the Covid-19 pandemic on filling local budgets]. Ekonomichnyi dyskurs [Economic discourse], 2, 86-94. DOI: https://doi.org/ 10.36742/2410-0919-2020-2-9.

9. Madeira A., Palrão T., Mendes A. S. The Impact of Pandemic Crisis on the Restaurant Business. Sustainability. 2021; 13(1):40. https://doi.org/10.3390/ su13010040.

10. Terziev, Venelin and Klimuk, Vladimir, Impact of Pandemic and Post-Pandemic Factors on Innovative Development of Industry (December 01, 2020). 19th RSEP International Economics, Finance \& Business Conference - Virtual/Online, 1-2 December 2020, Anglo-American University, Prague, Czechia, Available at SSRN: https://ssrn.com/abstract=3743458.

11. Holovne upravlinnia statystyky $\mathrm{v}$ Zakarpatskii oblasti [Main Department of Statistics in the Transcarpathian region] Retrieved April 28, 2021 from: http://www.uz.ukrstat.gov.ua. (in Ukrainian)

12. Zvedeni rezultaty anketuvannia efektyvnosti faktoriv prystosuvannia pidpryiemstv do funktsionuvannia $\mathrm{v}$ umovakh pandemii (2021) [Summary results of the survey of the effectiveness of factors of adaptation of enterprises to operate in a pandemic]. Vnutrishnii dokument. Uzhhorod: UzhNU. (in Ukrainian) 